\title{
Review of Ola Innset's Reinventing Liberalism. The Politics, Philosophy and Economics of Early Neoliberalism (1920-1947). Cham: Springer, 2020, 207 pp.
}

\author{
BRAM MELLINK \\ University of Amsterdam
}

Since the financial crisis of 2008, 'neoliberalism' has become a buzzword and academic research of the topic has exploded. Whereas the term became a catch-all concept in public debate, encompassing virtually all socio-economic developments disliked by the left, academics have mostly worked in the opposite direction. By retracing the steps of self-proclaimed neoliberals, they have detected an international network of neoliberal think-tanks of which the Mont Pèlerin Society, named after the Swiss Alpine village where it was established, is generally regarded as the central hub. In Reinventing Liberalism, a book based on his doctoral dissertation, the Norwegian historian Ola Innset provides a detailed analysis of the society's inaugural meeting in 1947.

From a methodological viewpoint, this may seem an easy task: the minutes of the first meeting have been well-preserved and many of its forty attendants kept archives of their own. Innset, however, faced a different challenge. Existing research regarding the neoliberal movement has demonstrated time and again that early self-proclaimed neoliberals refrained from establishing parliamentary parties of their own, and instead preferred to disseminate their market-oriented ideas within existing parties. They did so by means of a network of think-tanks, and according to most scholars the Mont Pèlerin Society was the cornerstone of this international network. Where better to look then than at the society's inaugural conference, which lasted a full two weeks? However, as Innset himself observes, "anyone who has been to a meeting or conference with more than a couple of people who are perfectly in tune with each other knows that these sorts of events are almost always somewhat disappointing" (170). This is Innset's challenge: the central importance attributed to the Mont Pèlerin Society justifies his study, but the author is well aware of the fact that conferences (especially those without tangible outcomes) are of limited importance in themselves. 
Innset tackles this issue in the first part of his book by linking the first meeting of the Mont Pèlerin Society to a longer historical trajectory. Its three chapters outline the establishment of what Innset calls 'the dual argument': the simultaneous stance of the neoliberals against socialism and classical liberalism. Chapters 2 and 3 are mostly concerned with the former. As Innset reminds us, socialism was relatively new as a large-scale political practice in the early inter-war years, with the recently established Soviet Union as its most prominent signpost. But although the Soviet Union led to uneasiness among liberal elites in the West, to say the least, market-oriented liberals, such as a certain Ludwig von Mises from the Austrian Chamber of Commerce, were even more appalled by socialist experiments taking place in their immediate surroundings. Experiments with 'Red Vienna' at the time fostered their fear that socialist ideas might take root in the heart of Europe which, according to Mises, would lead to the abolishment of liberty and the free economy as they knew it. In defense of liberalism, Mises set out to demonstrate the impossibility of 'socialist calculation': without free market prices, commensurability (weighing different means up against each other) would become impossible, which would turn socialist planning into an illusion.

It was only in the 1930s, Innset argues, that self-proclaimed liberals combined this 'knowledge argument' against planning with a devastating critique of the relation between socialism and totalitarianism. It was the American journalist Walter Lippmann who provided this ammunition against socialism in his book The Good Society, published in 1937. In this study, Lippmann criticized the rapid rise of state power under Roosevelt's New Deal and argued that the planning of production currently taking place also implied the planning of consumption, resulting in an expansion of economic planning, collectivism, and state power-a slippery slope towards totalitarianism. By employing the term 'totalitarianism', Innset points out, Lippmann adopted a term of socialist origin (developed to criticize the Soviet Union) and used it against the socialists. His analysis was taken up by the Austrian economist Friedrich Hayek, who had belonged to Mises' circles but who had recently fled to London. Hayek organized the so-called Lippmann Colloquium in 1938 to discuss Lippmann's central thesis regarding the intimate link between socialism and totalitarianism. This was the first occasion on which many central actors of the neoliberal movement from Europe and the United States met in real life, and adopted the term 'neoliberalism' to communicate their position. 
So far, Reinventing Liberalism mirrors the dominant storyline of current studies on early neoliberalism, and its first chapters rely heavily on Erwin Dekker's (2016) research on Austrian economics, and Serge Audier's (2008) work on the Lippmann Colloquium. Reinventing Liberalism takes a different turn when Innset works out 'the dual argument': the way in which neoliberals rejected socialism and laissez-faire, while embracing markets as 'mediators of modernity'. At the surface, this analysis seems conventional and it is certainly not as new as Innset implies. Although he rightly points out that historians such as Stedman Jones (2012) and Angus Burgin (2012) interpret neoliberalism as an (eventual) return to laissez-faire, Innset pays far less attention to the vast body of literature in which the neoliberals' rejection of laissez-faire serves as a vantage point for analyzing the 'retasking' of states (Peck 2010), the establishment of a new liberal 'thought collective' (Mirowski and Plehwe 2009), the neoliberals' departure from the 'fallacy of laissez-faire' (Slobodian 2018), and so forth. Despite this blind spot, Innset places the neoliberal dual argument in a new context: the neoliberals' shared skepticism of universal suffrage and mass democracy.

Innset demonstrates that such sentiments were widespread throughout the inter-war years, and were therefore not characteristic of neoliberalism per se. In socialist and social liberal circles, the work of Karl Mannheim captured the attention during the Second World War, due to the Hungarian sociologists' critique of mass societies and Mannheim's rather elitist proposal to 'plan for freedom'. This was what neoliberals hoped to avoid. Rather than domesticating free markets by means of planning (social liberalism) or allowing them to generate welfare for mass democracies without interference (laissez-faire), neoliberals proposed to secure the market from democratic decision-making, to put it beyond the control of the masses who had recently obtained universal (male) suffrage. The second part of Reinventing Liberalism, which is dedicated to the two-week conference in Mont Pèlerin, demonstrates how most of the Mont Pèlerin Society's members believed that core liberal principles-free markets, intellectual freedom, individual liberty-could only be upheld by safeguarding the market mechanism from democratically elected politicians and their constituencies. As a result, early neoliberals attempted to set market conditions through the state apparatus (for instance, by prohibiting monopolies and cartels), while deliberately pushing these social-economic policies outside the realm of democratic decision-making. 
Motivated by their aversion to socialism and (to a lesser extent) mass democracies, some pre-war neoliberals also explored whether the roads of liberalism and fascism could meet. Ludwig von Mises, for instance, opposed the 'interventionist' socio-economic policies of Italy and (Weimar) Germany in 1927, but considered fascism 'the lesser evil' in comparison to socialism. "It cannot be denied", he argued, "that Fascism and similar movements aiming at the establishment of dictatorships are full of the best intentions and that their intervention has, for the moment, saved European civilization. The merit that Fascism has thereby won for itself will live on eternally in history" (Mises [1927] 2005, 30). Such flirtations with fascism lessened as time wore on and a pre-war neoliberal such as Louis Rougier was excluded from the Mont Pèlerin Society due to his overt fascist sympathies. But the neoliberal's skepticism of mass democracy and its pressure groups-originally inspired by the fascist ideologue Carl Schmitt-would survive the Second World War, and Innset's most important contribution is that he demonstrates how this skepticism was key to the development of neoliberalism as a separate branch of liberalism.

Reinventing Liberalism is, above all, an intellectual history. It provides a well-written, accessible and concise account of the early neoliberals and their struggle-not only to combat socialism, but also to liberate themselves from the creed of laissez-faire and its (looser) ties with fascism. By analyzing this intellectual struggle in detail, Innset demonstrates once more that neoliberals are not the naïve believers in homo economicus they are so often made out to be, especially in public debate. Instead, early neoliberals struggled to align (the conditions for) individual liberty with state-fostered free markets. In doing so, they drove wedges, not only between classical liberals and themselves, but also between individual liberty and democratic decision-making.

\section{REFERENCES}

Audier, Serge. 2008. Le Colloque Lippmann: Aux Origines du Néo-libéralisme. Lormont: Le Bord de l'Eau.

Burgin, Angus. 2012. The Great Persuasion: Reinventing Free Markets since the Depression. Cambridge, MA: Harvard University Press.

Dekker, Erwin. 2016. The Viennese Students of Civilization: The Meaning and Context of Austrian Economics Reconsidered. Cambridge: Cambridge University Press.

Lippmann, Walter. 1937. An Inquiry into the Principles of the Good Society. Boston, MA: Little, Brown and Company.

Mirowski, Philip, and Dieter Plehwe, eds. 2009. The Road from Mont Pèlerin: The Making of the Neoliberal Thought Collective. Cambridge, MA: Harvard University Press. 
Mises, Ludwig. (1927) 2005. Liberalism: The Classical Tradition. Edited by Bettina Bien Greaves. Indianapolis, IN: Liberty Fund.

Peck, Jamie. 2010. Constructions of Neoliberal Reason. Oxford: Oxford University Press. Slobodian, Quinn. 2018. Globalists: The End of Empire and the Birth of Neoliberalism. Cambridge, MA: Harvard University Press.

Stedman Jones, Daniel. 2012. Masters of the Universe: Hayek, Friedman, and the Birth of Neoliberal Politics. Princeton, NJ: Princeton University Press.

Bram Mellink is assistant professor of Dutch history at the University of Amsterdam and postdoctoral researcher at Utrecht University. His research focuses on the development and dissemination of early neoliberal ideas and policy practices in the Netherlands (1945-1975).

Contact e-mail: <brammellink@uva.nl> 